\title{
Growth and Digestive Enzymatic Profile of Acipenser naccarii and Oncorhynchus mykiss Fed on Different Dietary Macronutrient Levels. A Comparative Study
}

\author{
Sanz $A^{1 *}$, Furné $\mathbf{M}^{1}$, Hidalgo $\mathbf{M C}^{1}$, Domezain $\mathbf{A}^{2}$ and García-Gallego $\mathbf{M}^{\mathbf{1}}$ \\ ${ }^{1}$ Department of Zoology, Faculty of Sciences, University of Granada, 18071 Granada, Spain \\ ${ }^{2}$ Bioteco, S.L, Spain
}

\begin{abstract}
This work provides a comparative study between sturgeon (Acipenser naccarii) and trout (Oncorhynchus mykiss) on the utilization of diets in which protein is partially replaced by carbohydrates and/or lipids, examining the fish growth and the possible adaptive response of the digestive enzymes. Positive relationship between amylase secretion and carbohydrate level in the diet for trout and between lipase secretion and lipid level in the diet in sturgeon were found. In this study we proved, once more, that sturgeon show a more favourable performance than trout when fed on diets with lower protein/energy ratios. This difference enables sturgeon to be fed diets with a lower protein content (approximately $10 \%$ lower) than that of the diets used to feed strictly carnivorous fish. The reduction of the dietary protein level could mean both a lower feed cost, and a lower nitrogenous wastage to the environment.
\end{abstract}

Keywords: Digestive; Nutrition; Fish; Sturgeon; Trout

\section{Introduction}

Fish feeding and nutrition are among the main concerns of fish culturists when interested in the rearing of a species new for fish farming. Salmonids feeding and nutrition are acceptably solved issues but this is not the case for other fish groups. Several sturgeon species are commonly cultured using readily available commercial salmonid diets $[1,2]$. These feeds often contain high proportions of crude protein and crude lipid from marine origin. Reliance on marine capture fisheries for aquafeeds has resulted in increased scrutiny over the past 60 years regard in the sustainability of aquaculture, given that more than $80 \%$ of marine fish stocks are nowadays considered as threatened in several degrees [3].

The sturgeon Acipenser naccarii is being cultured in fish farms of Spain and Italy for more than ten years. Previous studies of our team have reported that diets with a lower protein content and a lower protein/energy ratio than those usually present in the commercial foods for salmonid and other carnivorous fish, can be properly used by this sturgeon species $[4,5]$. Besides that, the digestive enzymatic pool of this sturgeon is more in tune with the corresponding to a species with an omnivorous lifestyle [6,7]. Finally, some enzyme activities involved in the main pathways of the intermediary metabolism show clear differences with respect to the corresponding to a strictly carnivorous fish as rainbow trout (Oncorynchus mykiss) [8,9]. A better utilization, by this species, of diets where carbohydrates and/or lipids partially replace protein, could lead to the manufacture of low-priced and environmentally less aggressive specific feeds.

The ability of an animal to transform and use nutrients supplied by the diet depends largely on its profile of digestive enzymes. In fish, digestive enzymes activities have been investigated to understand their nutritional requirements [10] since the understanding of the functioning of the digestive machinery helps to explain better the utilization of nutrients at the digestive level $[11,12]$. The pattern of digestive enzymes can also reflect the feeding habits of fish, whether carnivorous, herbivorous, or omnivorous [13].

With respect to the possible effect of the dietary constituents on digestive enzymatic activity, although it is generally accepted that protease, lipase and amylase activities change proportionately in response to the quantity of their respective substrates [14], several studies report that this can be largely modulated by different species $[11,15,16]$. It has been showed an adaptive response of amylase activity to dietary carbohydrates level [17-19]. Regarding to lipase activity in relation to the amounts of lipids supplied, there are studies showing contrary results depending on the species studied $[19,20]$. For the protease activity, several studies demonstrate that it is not inducible by an increase in dietary proteins $[18,21,22]$.

Continuing within the research line aimed to improve the knowledge on the nutrition of the sturgeon Acipenser naccarii and clarify its possible omnivorous habits, the present work provides a comparative study with a carnivorous fish (Oncorhynchus mykiss) on the utilization of diets in which protein is partially replaced by carbohydrates or lipids, examining the fish growth and the possible adaptive response in the digestive enzymes.

\section{Materials and Methods}

\section{Experimental diets}

For the assay, 3 experimental diets were formulated and manufactured, varying the proportion of macronutrients. The diet $\mathrm{P}$ contained a higher protein level $(46 \%)$ and a greater $\mathrm{P} / \mathrm{E}$ ratio $(20 \mathrm{~g} / \mathrm{MJ})$ than $\mathrm{L}-\mathrm{CH}$ and $\mathrm{L}$ diets (35\% of protein and $14 \mathrm{~g} / \mathrm{MJ}$, of $\mathrm{P} / \mathrm{E}$ ). In these two diets the protein was partially replaced by carbohydrates and lipids (diet L-CH) or only with lipids (diet L) (Table 1).

*Corresponding author: Sanz A, Department of Zoology, Faculty of Sciences University of Granada, 18071 Granada, Spain, Tel: +34 58 243243; E-mail: anasanz@ugr.es

Received November 22, 2014; Accepted December 10, 2014; Published January 12, 2015

Citation: Sanz A, Furné M, Hidalgo MC, Domezain A, García-Gallego M (2015) Growth and Digestive Enzymatic Profile of Acipenser naccarii and Oncorhynchus mykiss Fed on Different Dietary Macronutrient Levels. A Comparative Study. J Aquac Res Development 6: 300. doi:10.4172/2155-9546.1000300

Copyright: ( 2015 Sanz A, et al. This is an open-access article distributed under the terms of the Creative Commons Attribution License, which permits unrestricted use, distribution, and reproduction in any medium, provided the original author and source are credited. 
Citation: Sanz A, Furné M, Hidalgo MC, Domezain A, García-Gallego M (2015) Growth and Digestive Enzymatic Profile of Acipenser naccarii and Oncorhynchus mykiss Fed on Different Dietary Macronutrient Levels. A Comparative Study. J Aquac Res Development 6: 300. doi:10.4172/2155-9546.1000300

Page 2 of 6

\section{Animals}

A total of 270 sturgeons $(A$. naccarii) and 270 rainbow trout $(O$. mykiss) $2+$ years old and with an average initial weight of $1429.6 \pm 33.9$ and $381.3 \pm 38.9 \mathrm{~g}$, respectively, were used. Sturgeons and trout were maintained in 18 separate tanks ( 3 rectangular tanks/diet and species; $30 \mathrm{fish} / \operatorname{tank}$; tank of $3 \mathrm{~m}^{3}$ for sturgeon and $0.7 \mathrm{~m}^{3}$ for trout). Fish were obtained from the fish farm Sierra Nevada S.L. (Riofrío, Granada, Spain) where the experiment was conducted. The experiment lasted 3 months, in which the fish were fed twice per day (9:00 and 17:00 $\mathrm{h}$ ), the daily ration size being $1.5 \%$ of the initial body weight; the total food supply was corrected each month considering a theoretical monthly weight increase of $30 \%$. The maintenance was as at the fish farm. Culture density was $20 \mathrm{~kg} / \mathrm{m}^{3}$, and the water flow was $1 \mathrm{~L} / \mathrm{kg} /$ min. The water temperature was maintained at $14 \pm 1^{\circ} \mathrm{C}$ and oxygen at saturation.

All the procedures were conducted according to the guidelines of Council Directive 86/609/EEC (European Communities 1986) on the protection of animals used for experimental and other scientific purposes.

Weight increase was determined by individually weighing the animals (after a 24 hours fasting period) at the beginning and the end of the experiment ( $n=3$, three tanks by species and diet). At the end of the experimental period 12 sturgeon and 12 trout for each diet were used for measuring digestive enzyme activity. The complete digestive tracts, from oesophagus to the anus, were removed, after which the samples were immediately placed in liquid nitrogen and stored at $-80^{\circ} \mathrm{C}$ until analysed.

\section{Analytical methods}

The body composition and chemical composition of the diets were determined using the methods established by the AOAC (2004): moisture by drying of the sample at $105{ }^{\circ} \mathrm{C}$ until constant weight; ash by incineration in an oven at $500^{\circ} \mathrm{C}$ for $12 \mathrm{~h}$; lipid content by the Soxhlet extraction method with diethyl ether and protein content by the Kjeldahl method (Nx6.25).

The specific growth rate (SGR) was calculated as SGR $=[(\ln$ final weight - ln initial weight) / number of days] x 100 .

\section{Enzymatic determinations}

For measurements of digestive enzymatic activities, the complete digestive tract of each fish was homogenized by using an electric homogenizer (Heidolph Instruments, Schwabach, Germany) ice cooled. For the homogenization, a $100 \mathrm{mM}$ Tris- $\mathrm{HCl}$ buffer with 0.1 $\mathrm{mM}$ EDTA and $0.1 \%$ triton $\mathrm{X}-100, \mathrm{pH} 7.8$, was used at a proportion of $1 \mathrm{~g}$ tissue in $9 \mathrm{ml}$ of buffer. The homogenates were centrifuged at $30000 \mathrm{xg}$ for $30 \mathrm{~min}$ at $4^{\circ} \mathrm{C}$ in a Kontron centrifuge model Centrikon H-401 (Hermle, Switzerland). After centrifugation, the supernatant was collected and frozen at $-80^{\circ} \mathrm{C}$ until analysed.

The proteolytic activity was estimated by using the casein-hydrolysis method according to Walter (1984). The enzymatic determination was made at several $\mathrm{pH}$ values over the physiological range of the digestive tract. The buffers used were KCl-HCl $0.1 \mathrm{M}(\mathrm{pH} \mathrm{1.5),} \mathrm{glycine-} \mathrm{HCl} 0.2$ $\mathrm{M}$ ( $\mathrm{pH} 3.0$ ), citrate $0.1 \mathrm{M}$-phosphate $0.2 \mathrm{M}$ (pH 4.0 and 7.0), Tris$\mathrm{HCl} 0.1 \mathrm{M}$ (pH 8.5 and 9.0) and glycine- $\mathrm{NaOH} 0.1 \mathrm{M}(\mathrm{pH} 10.0)$. The total proteolytic activity was calculated as the sum of the enzymatic activity at different $\mathrm{pHs}$. The enzymatic reaction mixtures, composed by a casein solution $(1 \% \mathrm{w} / \mathrm{v})$ in distilled water $(0.25 \mathrm{ml})$, buffer $(0.25$ $\mathrm{ml})$, and extract $(0.1 \mathrm{ml})$ were incubated for $1 \mathrm{~h}$ at $37^{\circ} \mathrm{C}$. The reactions were stopped by the addition of $0.6 \mathrm{ml}$ of trichloroacetic acid at $8 \%$ $(\mathrm{w} / \mathrm{v})$. After being kept for $1 \mathrm{~h}$ at $4^{\circ} \mathrm{C}$, the samples were centrifuged at $1800 \mathrm{xg}$ for $10 \mathrm{~min}$, and the absorbance of the supernatant measured at $280 \mathrm{~nm}$. The extracts were added to the blank tubes at the end of the incubation just before adding the trichloroacetic acid. The samples were assayed in triplicate and blanks in duplicate. L-tyrosine was used as a standard. One unit of total proteolytic activity was defined as the quantity of enzyme that released $1 \mathrm{mmol}$ of tyrosine $/ \mathrm{ml} / \mathrm{min}$. Although there are many specific techniques to determine the activity of each proteolytic enzyme, we chose a non-specific approach [23]. This method enables the quantification of different proteolytic activities as a function of $\mathrm{pH}$ : the activity of pepsin (acidic $\mathrm{pH}$ ), chymotrypsin, and trypsin activity (neutral or slightly basic $\mathrm{pH}$ ) and other enzymes such as carboxypeptidases, elastases, and collagenases (basic $\mathrm{pH}$ ).

The $\alpha$-amylase was determined by the starch-hydrolysis method, according to Robit and Whelan [24]. The enzymatic reaction mixture consisted of $2 \%(\mathrm{w} / \mathrm{v})$ starch solution $(0.125 \mathrm{ml}), 0.1 \mathrm{M}$ citratephosphate buffer at pH $7.5(0.125 \mathrm{ml})$, and a digestive extract $(0.05 \mathrm{ml})$. The reaction mixture was incubated for $1 \mathrm{~h}$ at $37^{\circ} \mathrm{C}$. Absorbance was determined at $600 \mathrm{~nm}$. For the blank tubes, the same procedure was followed except for the addition of the extract just after incubation. Maltose was used as a standard, and the activity unit of $\alpha$-amylase was defined as the quantity of enzyme that produced $1 \mathrm{mmol}$ of maltose/ $\mathrm{ml} / \mathrm{min}$.

The lipase activity was determined by the evaluation of the degradation of triacylglycerols, diacylglycerols, and monoacylglycerols to free fatty acids, following the method of Bier [25]. For the emulsion, a $1 \%$ solution of 11 of polyvinyl alcohol (PVA) in distilled water was used. Then, $5 \mathrm{ml}$ of $0.1 \mathrm{~N} \mathrm{HCl}$ were added, heating to $75-85^{\circ} \mathrm{C}$ for 1 $\mathrm{h}$, followed by cooling, filtering, and adjusting $\mathrm{pH}$ to 8.0 with $0.1 \mathrm{~N}$ $\mathrm{NaOH}$. To an aliquot of the above solution, virgin olive oil was added to a substrate concentration of $0.1 \mathrm{M}$. The mixture was emulsified for 5 min. The reaction mixture was composed of a PVA solution-emulsified substrate $(1 \mathrm{ml}), \mathrm{McIl}$ vaine buffer at $\mathrm{pH} 8(0.5 \mathrm{ml})$, and digestive extract $(0.5 \mathrm{ml})$. The McIlvaine buffer was prepared from $0.1 \mathrm{M}$ citric acid and $0.2 \mathrm{M}$ bisodium phosphate. The reaction mixture was incubated for $4 \mathrm{~h}$ at $37^{\circ} \mathrm{C}$. After incubation, $3 \mathrm{ml}$ of a 1:1 ethanol-acetone solution were added to stop the reaction and break the emulsion. A few drops of $1 \%$ phenolphthaleine in ethanol were added to the reaction mixture and titrated with $0.01 \mathrm{M} \mathrm{NaOH}$. For the blank tubes, the same procedure was followed but with boiled enzyme. Porcine type-II pancreatic lipase (Sigma L3126) was used as a standard. One unit of lipase activity was defined as the hydrolysis of 1.0 microequivalent of fatty acids from triacylglycerols in $1 \mathrm{~h}$ at $\mathrm{pH} 7.7$ and $37^{\circ} \mathrm{C}$.

Protein content of the supernatant solutions was determined by the Bradford method [26], using bovine-serum albumin as the standard.

\begin{tabular}{|c|c|c|c|}
\hline & \multicolumn{3}{|c|}{ Diet } \\
\hline & L-CH & L & P \\
\hline Crude protein & 35.22 & 35.00 & 45.58 \\
\hline Lipid & 25.10 & 29.66 & 18.50 \\
\hline N-free extract (NFE) & 38.16 & 30.00 & 31.94 \\
\hline Ash & 2.55 & 3.80 & 3.98 \\
\hline Gross energy (MJ/Kg) & 24.64 & 25.30 & 22.41 \\
\hline Protein/energy ratio (g/MJ) & 14.29 & 13.74 & 20.03 \\
\hline
\end{tabular}

${ }^{*}$ Caloric values used were $23.4,39.2$, and $17.2 \mathrm{KJ} / \mathrm{g}$ of protein, lipid, and carbobydrates (NFE), respectively

Table 1: Proximate composition of the experimental diets ( $\mathrm{g} / 100 \mathrm{~g}$ dry mater) 
Citation: Sanz A, Furné M, Hidalgo MC, Domezain A, García-Gallego M (2015) Growth and Digestive Enzymatic Profile of Acipenser naccarii and Oncorhynchus mykiss Fed on Different Dietary Macronutrient Levels. A Comparative Study. J Aquac Res Development 6: 300. doi:10.4172/2155-9546.1000300

Page 3 of 6

\section{Statistical Analysis}

The data were analysed by univariate general linear model using SPSS version 20.0 for Windows software package. Significant differences among means $(P<0.05)$ in the same species were determined by the Tukey's multiple-range test. For the analysis of the dependence between two variables, the Pearson correlation coefficient was estimated and the data were adjusted by linear regression.

\section{Results}

The values of SGR determined in the different groups (Table 2) show that trout exhibited a higher relative growth rate. Concerning the effect of diet, sturgeons fed on diets L and L-CH grew significantly more than those fed on diet $\mathrm{P}$ (high protein) while in trout the situation was just the opposite since diet $\mathrm{P}$ produced the best growth rate.

The digestive enzyme activities of fish fed on the three experimental diets are shown in Table 3. Trout exhibited higher activities of both, protease and lipase, than sturgeon irrespective of the diet fed. Species did not affect amylase activity. Concerning the diet composition, the results revealed a linear correlation $\left(2.3109 \mathrm{X}-31.242 ; \mathrm{R}^{2}=0.869\right.$; $\mathrm{P}<0.05)$ between the dietary carbohydrate level $(\mathrm{X})$ and the digestive amylase activity $(\mathrm{Y})$ for trout. A similar correlation $(0.6343 \mathrm{X}+4.064$; $\left.\mathrm{R}^{2}=0.968 ; \mathrm{P}<0.01\right)$ but between the lipase activity $(\mathrm{Y})$ and the dietary lipid level (X) was detected in sturgeon.

Concerning the proteases activity, diets with higher levels of lipids ( $\mathrm{L}$ and $\mathrm{L}-\mathrm{CH}$ ) induced a significantly increased protease activity in sturgeon. This was not the case in trout (Table 3 ).

The relative proportions in different enzymatic activities for trout and sturgeon fed the 3 experimental diets are shown in Figure 1. It can be seen that amylase activity was relatively higher in sturgeon than in trout fed on experimental diets while protease activity was relatively higher in trout irrespective of the diet fed.

Protease activity measured at different $\mathrm{pHs}$ showed, in both species and for the three experimental diets, the same trend that total protease activity (Table 4) being the higher in L-CH diet (the diet with high levels of bots, lipid and carbohydrates, but le lower protein level). The ratio between acid proteases (sum of the activities measured at $\mathrm{pHs} 1.5$, 3.0, and 4.0) and neutro-basic proteases (sum of the activities measured at pHs 7.0, 8.5, 9.0 and 10.0) is shown in the same table. This ratio was higher in trout in comparison with sturgeon for all diets.

\section{Discussion}

In the present study, the diet with both the highest protein level and protein/energy ratio (diet $\mathrm{P}$ ) supported the highest growth rate in trout (O. mykiss). This was not the case for sturgeon (A. naccarii), where a reduction in the protein/energy ratio achieved by a diminution in the protein level joined to, an increase in the carbohydrate and lipid ones (diet L-CH) or, alternatively, to an increase in the lipid level (diet L), did not negatively affect the growth promoted. This finding indicates that trout, as carnivores, could have higher protein needs. Once more, our studies reveal that in this sturgeon species, the replacement of dietary protein by lipids or carbohydrates does not negatively affect growth and other nutritional indices, as reported previously [4]. Moreover, other studies on intermediary metabolism and digestive enzymes in this sturgeon species could reflect a feeding habit closer to the omnivory than to a strictly carnivorous regime [6,7]. In their natural habitats, sturgeon ingests a level of carbohydrates higher than carnivorous species [27], in short, it can be said that this species of sturgeon is "more omnivore" than trout.
In the reported previous studies as in this one it has been found that the amylase activity in sturgeon was relatively greater than in trout and also that the amylase activity was relatively higher than the activities of proteases and lipase (Figure 1). Besides that, the results for the activities of the digestive enzymes revealed a linear correlation between the carbohydrate level in the diet and the amylase activity in trout but not in sturgeon.

Few previous studies have investigated the possible adaptation of fish digestive enzymes activities to diet composition. It was expected that an increase in a given dietary nutrient would produce an increase in the amount and/or activity of the enzymes used to digest it. The finding of this study that the amylase activity in trout increased in response to raising dietary carbohydrate level agrees with previous results for other fish species [17-19].

In contrast, no adaptation of the amylase activity was found in sturgeon in response to different dietary carbohydrate levels. A number of authors have indicated that the activity of this enzyme does not vary with diet composition even in fish with different nutritional habits $[15,28,29]$.

It is possible that the increased activity of the amylase in response to an increase of dietary carbohydrates level depends on the food habits of the fish. So an omnivorous fish, just as this sturgeon seems to be, has a digestive amylase activity enough to perform the digestion of carbohydrates regardless of their level in the diet (at least, within a certain range) and, by this reason, no adaptive response was found in this species, contrary to what was found in the trout. The presence of carbohydrates in the normal diet of a carnivorous fish, such as trout, is usually scarce and so an "artificial" increase in the amount of this nutrient in food involves the "necessity" on an adaptive response mediated by an increase of digestive amylase activity.

Few studies have been performed on fish digestive lipase activity. In these study, we found that, in the sturgeon, occurred an increase in this activity in response to an increase of dietary lipids, which was reflected by a positive correlation between both variables. No such response was detected in trout. The level of dietary lipids in a strictly carnivorous animal, as the trout, is considered, is usually greater than the corresponding to the feeding regimen of herbivorous/omnivorous animals. In these and other previous studies [6,7], we have shown that

\begin{tabular}{|l|l|c|c|c|c|c|c|c|}
\hline & & \multicolumn{3}{|c|}{ Diet } & \multicolumn{5}{c|}{ Significance } \\
\hline & Species & L-CH & L & P & rsm & Diet & Species & Diet * Species \\
\hline $\begin{array}{l}\text { Initial } \\
\text { weight } \\
\text { (Kg) }\end{array}$ & Sturgeon & 63.33 & 62.96 & 64.70 & & & & \\
\hline & Trout & 17.52 & 16.86 & 17.10 & & & & \\
\hline $\begin{array}{l}\text { Final } \\
\text { weight } \\
\text { (Kg) }\end{array}$ & Sturgeon & 81.29 & 81.53 & 77.28 & & & & \\
\hline & Trout & 28.27 & 25.29 & 40.18 & & & & \\
\hline SGR & Sturgeon & $0.29^{\mathrm{a}}$ & $0.29^{\mathrm{a}}$ & $0.20^{\mathrm{b}}$ & 0.04 & 0.010 & 0.000 & 0.001 \\
\hline & Trout & $0.53^{\mathrm{b}}$ & $0.45^{\mathrm{b}}$ & $0.95^{\mathrm{a}}$ & & & & \\
\hline
\end{tabular}

\section{\#SGR: standard growth rate}

$\mathrm{a}, \mathrm{b}, \mathrm{c}$ Values within each row with different superscripts are significantly different $(p<0.05)$

* These values are significantly different from the corresponding to the other species $(p<0.05)$

Table 2: Effects of dietary composition of the growth rate of the different groups ( $n=3$ replicated tanks/diet) 
Citation: Sanz A, Furné M, Hidalgo MC, Domezain A, García-Gallego M (2015) Growth and Digestive Enzymatic Profile of Acipenser naccarii and Oncorhynchus mykiss Fed on Different Dietary Macronutrient Levels. A Comparative Study. J Aquac Res Development 6: 300. doi:10.4172/2155-9546.1000300

Page 4 of 6

\begin{tabular}{|c|c|c|c|c|c|c|c|c|}
\hline \multirow[b]{2}{*}{ Enzyme } & \multirow[b]{2}{*}{ Species } & \multicolumn{3}{|c|}{ Diet } & \multirow[b]{2}{*}{ rsm } & \multicolumn{3}{|c|}{ Significance } \\
\hline & & $\mathrm{L}-\mathrm{CH}$ & L & $\mathrm{P}$ & & Diet & Species & Diet * Species \\
\hline \multirow{2}{*}{ Amylase } & Sturgeon & $149.28^{a}$ & $148.61^{\mathrm{a}}$ & $93.65^{b}$ & \multirow{2}{*}{7.45} & \multirow{2}{*}{0.012} & \multirow{2}{*}{0.641} & \multirow{2}{*}{0.021} \\
\hline & Trout & $160.72^{\mathrm{a}}$ & $91.59^{b}$ & $121.63^{\mathrm{ab}}$ & & & & \\
\hline \multirow{2}{*}{ Lipase } & Sturgeon & 24.75 & 25.45 & 11.96 & \multirow{2}{*}{2.48} & \multirow{2}{*}{0.304} & \multirow{2}{*}{0.001} & \multirow{2}{*}{0.008} \\
\hline & Trout & $39.29^{*}$ & 24.15 & $42.81^{*}$ & & & & \\
\hline \multirow{2}{*}{ Protease } & Sturgeon & $38.95^{\mathrm{a}}$ & $28.11^{\mathrm{ab}}$ & $19.19^{b}$ & \multirow{2}{*}{6.17} & \multirow{2}{*}{0.001} & \multirow{2}{*}{0.000} & \multirow{2}{*}{0.233} \\
\hline & Trout & $110.59^{a *}$ & $80.41^{\mathrm{b*}}$ & $85.02^{\mathrm{ab*}}$ & & & & \\
\hline
\end{tabular}

$a, b, c$ Values within each row with different superscripts are significantly different $(p<0.05)$

* These values are significantly different from the corresponding to the other species $(p<0.05)$

Table 3: Effects of dietary composition and species on the activity of some digestive enzymes (U/mg protein) ( $n=12,4 /$ each replicate)

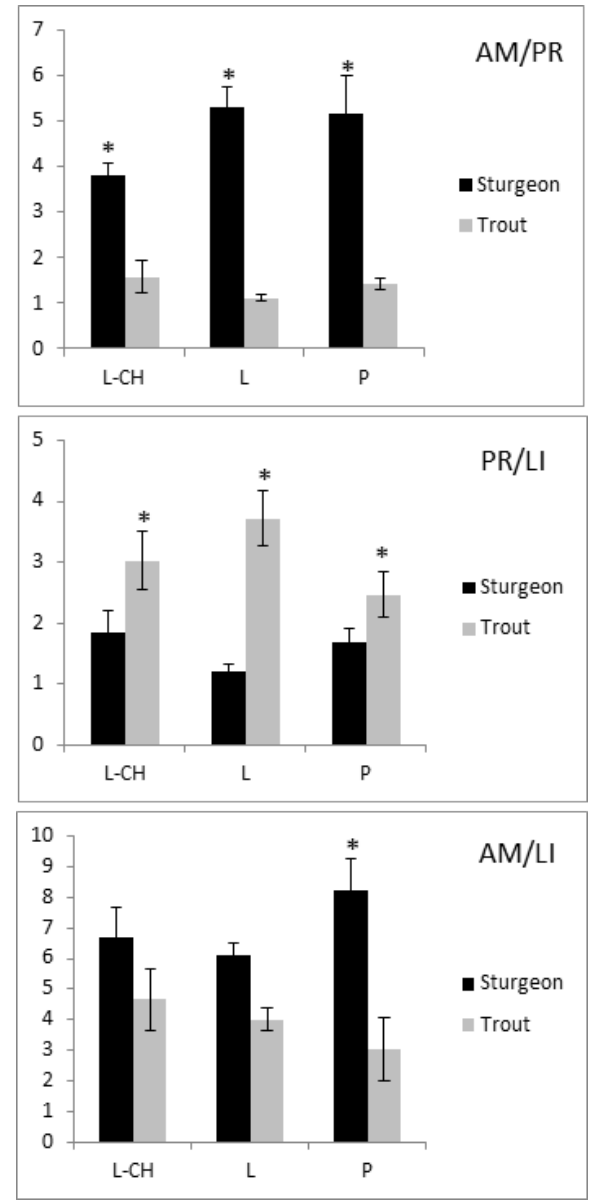

Figure 1: Effects of diet composition ( $\mathrm{L}-\mathrm{CH}, \mathrm{L}, \mathrm{P}$; see Table 1) and species (sturgeon, trout) on

digestive enziymes activities ratio (AM/PR: amylase/protease; PR/LI: protease/ lipase; AM/LI: amylase/lipase).

*Indicates significant differences between species $(p<0.05)$.

No significant differences among diets were detected in any case.

the lipase activity was higher in trout than in sturgeon when fed with the same control diet. The lipase activity usually found trout in the digestive tract could be sufficient to digest the dietary lipids regardless of their level in diet (at least within a certain range); on the contrary, in sturgeon an increase in the amount of lipids provided with food must provoke a raising in lipase secretion as a part of an adaptive response to an unusual circumstance.

This contrast between species was also reported in the few studies available in the literature. Specifically, De Almeida [19] found a higher lipase activity with increased dietary lipids for Colossoma macropomum, whereas other studies with carp do not find this response [20].

Concerning to the proteases activity we found that sturgeon fed diets with higher lipids and lower protein levels showed a higher protease activity, while this circumstance was not detected in this enzymatic activities when measured in trout (Table 3).

Several authors have previously reported the absence of effects of dietary composition on proteases activities in other species such as in Tilapia mossambica [21], Brycon cf. melanopterus [22], Dicentrarchus labrax [17] and Pseudoplatystoma corruscans [18]. However, in agreement with our findings for sturgeon, Papoutsoglou and Lyndon [30] found a higher protease activity in Anarhichas minor when fed on less protein and/or more carbohydrates diets. These authors indicate that the response to lower dietary protein content could trigger increased proteases secretion to improve the digestion and utilisation of the reduced available protein. This finding agrees with the results of Gangadhara [28] and Mohanta [31] in Labeo rohita (a herbivorous species) and Puntius gonionotus (an omnivorous species), respectively.

In this study, the protease activity measured at different $\mathrm{pHs}$ reflected the situation previously described for global protease activity. The dietary composition had no a clear effect on the profile of proteases activities measured at different pHs (Table 4). In every case, protease activity was higher in trout than in sturgeon and neutral more basic protease predominated over acid protease. However, the ratio between acid protease and neutral more basic protease was also higher in trout (carnivorous) than in sturgeon (omnivorous) (Table 4). A higher activity of acid protease in carnivorous fish has been shown by other authors in Sparus aurata [32], Oncorhynchus mykiss and Anguilla anguilla [11], Scopthalmus maximus [33] and Symphysodon aequifasciata.

In summary, we have found a certain adaptive response of the amylase activity in trout, in response to increasing dietary carbohydrates levels; a similar situation was found for lipase activity in sturgeon, as dietary lipids level increased. According to this study, we could state that, under normal conditions, the activity of digestive enzymes of these fish is enough to digest the nutrients usually present in greater proportion in their natural foods, so, variations in the amount of those nutrients in the diet, do not involve any adaptive response. On the contrary, when a nutrient appears in a reduced proportion in the natural food of one fish species, its inclusion in higher levels in an artificial diet can lead to an adaptive response to ensure the digestion of that nutrient. Likely, proteases activities are present in both species at a level enough to ensure adequate digestion of dietary proteins. In other words, the digestive enzymes adaptive response of a given species depends on its feeding habits and, therefore, the study of that response can shed light on the nature of those habits.

Moreover, in this study we proved, once more, that sturgeon shows 
Citation: Sanz A, Furné M, Hidalgo MC, Domezain A, García-Gallego M (2015) Growth and Digestive Enzymatic Profile of Acipenser naccaril and Oncorhynchus mykiss Fed on Different Dietary Macronutrient Levels. A Comparative Study. J Aquac Res Development 6: 300. doi:10.4172/2155-9546.1000300

Page 5 of 6

\begin{tabular}{|c|c|c|c|c|c|c|c|c|}
\hline \multirow[b]{2}{*}{ Protease } & \multirow[b]{2}{*}{ Species } & \multicolumn{3}{|c|}{ Diet } & \multirow[b]{2}{*}{$\mathrm{rsm}$} & \multicolumn{3}{|c|}{ Significance } \\
\hline & & $\mathrm{L}-\mathrm{CH}$ & $\mathrm{L}$ & $\mathrm{P}$ & & Diet & Species & Diet * Species \\
\hline \multirow{2}{*}{$\mathrm{pH} 1.5$} & Sturgeon & $4.90^{\mathrm{a}}$ & $3.77^{\mathrm{b}}$ & $2.18^{c}$ & \multirow{2}{*}{1.15} & \multirow{2}{*}{0.000} & \multirow{2}{*}{0.000} & \multirow{2}{*}{0.001} \\
\hline & Trout & $19.99^{a *}$ & $11.94^{b *}$ & $14.61^{\mathrm{b} *}$ & & & & \\
\hline \multirow{2}{*}{ pH 3.0} & Sturgeon & $6.47^{a}$ & $4.67^{\mathrm{b}}$ & $2.64^{c}$ & \multirow{2}{*}{1.15} & \multirow{2}{*}{0.021} & \multirow{2}{*}{0.000} & \multirow{2}{*}{0.316} \\
\hline & Trout & $18.77^{*}$ & $14.04^{*}$ & $15.84^{*}$ & & & & \\
\hline \multirow{2}{*}{$\mathrm{pH} 4.0$} & Sturgeon & 0.00 & 0.49 & 0.35 & \multirow{2}{*}{0.19} & \multirow{2}{*}{0.235} & \multirow{2}{*}{0.000} & \multirow{2}{*}{0.007} \\
\hline & Trout & $2.49^{*}$ & $1.20^{*}$ & $2.13^{*}$ & & & & \\
\hline \multirow{2}{*}{ pH 7.0} & Sturgeon & $6.13^{a}$ & $4.35^{b}$ & $2.89^{c}$ & \multirow{2}{*}{1.07} & \multirow{2}{*}{0.002} & \multirow{2}{*}{0.000} & \multirow{2}{*}{0.111} \\
\hline & Trout & $18.47^{\mathrm{ab} *}$ & $12.84^{\mathrm{c} *}$ & $15.17^{\mathrm{bc} *}$ & & & & \\
\hline \multirow{2}{*}{$\mathrm{pH} 8.5$} & Sturgeon & $6.98^{a}$ & $5.02^{b}$ & $3.67^{b}$ & \multirow{2}{*}{1.01} & \multirow{2}{*}{0.005} & \multirow{2}{*}{0.000} & \multirow{2}{*}{0.588} \\
\hline & Trout & $18.15^{*}$ & $13.81^{*}$ & $13.77^{*}$ & & & & \\
\hline \multirow{2}{*}{ pH 9.0} & Sturgeon & $7.33^{a}$ & $5.01^{\mathrm{b}}$ & $3.79^{b}$ & \multirow{2}{*}{0.93} & \multirow{2}{*}{0.005} & \multirow{2}{*}{0.000} & \\
\hline & Trout & $16.70^{*}$ & $13.86^{*}$ & $12.34^{*}$ & & & & 0.934 \\
\hline & Sturgeon & $7.14^{a}$ & $4.79^{b}$ & $3.67^{\mathrm{b}}$ & & & & \\
\hline $\mathrm{pH} 10.0$ & Trout & $16.01^{*}$ & $12.71^{*}$ & $11.16^{*}$ & 0.85 & 0.001 & 0.000 & 0.180 \\
\hline $\mathrm{AnH}^{1}$ & Sturgeon & $11.37^{\mathrm{a}}$ & $8.93^{b}$ & $5.17^{c}$ & 242 & 0000 & 0000 & 0058 \\
\hline АрН & Trout & $41.25^{a *}$ & $27.18^{\mathrm{b} *}$ & $32.58^{\mathrm{ab*}}$ & $2.4 \angle$ & 0.000 & 0.000 & 0.058 \\
\hline $\mathrm{NBpH}^{1}$ & Sturgeon & $27.58^{\mathrm{a}}$ & $19.17^{b}$ & $14.01^{\mathrm{b}}$ & 380 & 0.001 & 0000 & 0615 \\
\hline IVDPR & Trout & $69.33^{*}$ & $53.23^{*}$ & $52.44^{*}$ & 0.00 & 0.001 & 0.000 & 0.015 \\
\hline $\mathrm{AnH} / \mathrm{NBnH}^{1}$ & Sturgeon & $0.41^{\mathrm{ab}}$ & $0.47^{\mathrm{a}}$ & $0.37^{b}$ & 0.02 & 0755 & & \\
\hline ART IINDTI I & Trout & $0.61^{*}$ & 0.51 & $0.62^{*}$ & 0.02 & 0.150 & 0.000 & 0.003 \\
\hline
\end{tabular}

${ }^{1} \mathrm{ApH}$ : total acid protease activity $(\mathrm{pH} 1.3-4.0) ; \mathrm{NBpH}$ : total neutral/basic protease activity $(\mathrm{pH} 7.0-10.0) ; \mathrm{ApH} / \mathrm{NBpH}: \mathrm{ApH} / \mathrm{NBpH}$ ratio

$a, b, c$ Values within each row with different superscripts are significantly different $(p<0.05)$

* These values are significantly different from the corresponding to the other species $(p<0.05)$

Table 4: Effects of dietary composition and species on the digestive protease activity at different pHs (U/mg protein) ( $n=12,4 /$ each replicate)

a higher ability to use with profit for growth diets with lower protein/ energy ratios than trout does. This difference enables sturgeon to be fed on diets with an approximately $10 \%$ lower protein content than that of the diets used for the fish farming of a strictly carnivorous fish such as trout is. The reduction of protein in the diet means a lower feed cost and, also, a lower nitrogenous wastes production and releasing to the environment.

\section{Acknowledgements}

This work was conducted with the help of a project from the Spanish Ministerio de Educación y Ciencia (CGL2006/12193).

\section{References}

1. Celikkale MS, Memis EE, Cagiltay F (2005) Growth performance of juvenile Russian Sturgeon (Acipenser gueldenstaedtii Brandt and Ratzenburg, 1833) at two stocking densities in net cages. Journal of Applied Ichthyology 21: 14-18.

2. Liu $H$, Wu X, Zhao W, Xue M, Guo L, et al. (2009) Nutrients apparent digestibility coefficients of selected protein sources for juvenile Siberian Sturgeon (Acipenser baerii Brandt), compared by two chromic oxide analyses methods. Aquaculture Nutrition 15: 650-656.

3. http://www.fao.org/docrep/013/i1820e/i1820e.pdf

4. Sanz A, García-Gallego M, de la Higuera M, Domezain J, Domezain A (2005) Piensos para la alimentación del esturión desde los seis meses de edad hasta tamaño comercial. University of Granada, Spain.

5. Garcia-Gallego M, Domezain A, de la Higuera M, Hidalgo MC, Furné M, et al (2009) On nutrition and feeding studies as the basis for the culture of different sturgeon species. Biology 29: 215-234.

6. Furné M, Hidalgo MC, López A, García-Gallego M, Morales AE, et al. (2005) Digestive enzyme activities in Adriatic sturgeon Acipenser naccarii and rainbow trout Oncorhynchus mykiss. A comparative study. Aquaculture 250: 391-398.

7. Furné $M$, García-Gallego $M$, Hidalgo MC, Morales $A E$, Domezain A, et al. (2008) Effect of starvation and refeeding on digestive enzyme activities in sturgeon (Acipenser naccarii) and trout (Oncorhynchus mykiss). Biochem Physiol A Mol Integr Physiol 149: 420-425

8. Furné M, Sanz A, García-Gallego M, Hidalgo MC, Domezain A, et al. (2009) Metabolic organization of the sturgeon Acipenser naccarii. A comparative study with rainbow trout Oncorhynchus mykiss. Aquaculture 289: 161-166.
9. Furné M, Morales AE, Trenzado CE, García-Gallego M, Carmen Hidalgo M, et al. (2012) The metabolic effects of prolonged starvation and refeeding in sturgeon and rainbow trout. J Comp Physiol B 182: 63-76.

10. Divakaran S, Kim BG, Ostrowski AC (1999) Digestive enzymes present in Pacific threadfin Polydactylus sexfilis (Bloch and Schneider, 1801) and bluefin trevally Caranx melampygus (Cuvier 1833). Aquaculture Research 30: 781 787.

11. Hidalgo MC, Urea E, Sanz A (1999) Comparative study of digestive enzymes in fish with different nutritional habits. Proteolytic and amylase activities Aquaculture 170: 267-283.

12. Kolkovski S (2001) Digestive enzymes in fish larvae and juveniles -implications and applications to formulated diets. Aquaculture 200: 181-201

13. Hofer R, Kóck G (1989) Method for quantitative determination of digestive enzymes in fish larvae. Polskie Archiwum Hydrobiologii 36: 439-441.

14. Lhoste EF, Rszlewicz M, Gueugneau AM, Coning T (1994) Adaptation of exocrine pancreas to dietary proteins: effect of the nature of protein and rat strain on enzyme induction and messenger mRNA levels. J Nutri Biochem 5 : 84-89.

15. Chakrabarti I, Gani MA, Chaki KK, Surm R, Misra KK (1995) Digestive enzymes in 11 freshwater teleost fish species in relation to food habit and niche segregation. Comparative Biochemistry and Physiology A 112: 167-177

16. Chan AS, Horn MH, Dickson KA, Gawlicka A (2004) Digestive enzyme activities in carnivores and herbivores: comparisons among four closely related prickleback fishes (Teleostei: Stichaeidae) from a California rocky intertidal habit. J Fish Biol 65: 848-858.

17. Cahu CL, Zambonino-Infante JL (1994) Early weaning of sea bass (Dicentrarchus labrax) larvae with a compound diet: effect on digestive enzymes. Comparative Biochemistry and Physiology A 109: 213-222.

18. Lundstedt LM, Melo JF, Moraes G (2004) Digestive enzymes and metabolic profile of Pseudoplatystoma corruscans (Teleostei: Siluriformes) in response to diet composition. Comp Biochem Physiol B Biochem Mol Biol 137: 331-339.

19. De Almeida LC, Lundstedt LM, Moraes G (2006) Digestive enzyme response of tambaqui (Colossoma macropomum) fed on different levels of protein and lipid. Aquaculture Nutrition 12: 443-450.

20. Manjappa K, Keshavanath P, Gangadhara B (2002) Growth performance of common carp, Cyprinus carpio, fed varying lipid levels through low protein 
Citation: Sanz A, Furné M, Hidalgo MC, Domezain A, García-Gallego M (2015) Growth and Digestive Enzymatic Profile of Acipenser naccarii and Oncorhynchus mykiss Fed on Different Dietary Macronutrient Levels. A Comparative Study. J Aquac Res Development 6: 300. doi:10.4172/2155-9546.1000300

diet, with a note on carcass composition and digestive enzyme activity. Acta Ichtyologica et Piscatoria 32: 145-155.

21. Nagase G (1964) Contribution to the physiology of digestion in Tilapia mossambica: digestive enzymes and the effects of diets on their activity. Zeitschrift fur Vergleichende Physiologie 49: 270-284.

22. Reimer G (1982) The influence of diet on the digestive enzymes of the Amazon fish Matrincha, Brycon cf. melanopterus. J Fish Bio 21: 637-642.

23. Munilla-Morán R, Stark JR (1989) Protein digestion in early turbot larvae Scophthalmus maximus (L.). Aquaculture 81: 315-327.

24. Robit JF, Whelan WJ (1968) The ß-amylases. Academic Press, London, United Kingdom.

25. Bier M (1955) Lipases. Methods in Enzymology 1: 627-642.

26. Bradford MM (1976) A rapid and sensitive method for the quantitation of microgram quantities of protein utilizing the principle of protein-dye binding Anal Biochem 72: 248-254.

27. Soriguer MC, Domezain J, Domezain A, Bernal M, Esteban C, et al. (2007) An approximation of the feeding habits of Acipenser naccarii (Bonaparte 1836) in an artificial river. J Applied Ichthyology 15: 348
28. Gangadhara B, Nandeesha MC, Barghese TJ, Keshavanath P (1997) Effect of varying protein and lipid levels on the growth of rohu, Labeo rohita. Asian Fisheries Science 10: 139-147.

29. Debnath D, Pal AK, Sahu NP, Yengkokpam S, Baruah K, et al. (2007) Digestive enzymes and metabolic profile of Labeo rohita fingerlings fed diets with different crude protein levels. Comparative Biochemistry and Physiology B 146: 107-114.

30. Papoutsoglou ES, Lyndon AR (2006) Digestive enzymes of Anarhichas minor and the effect of diet composition on their performance. J Fish Biol 69: 446-460.

31. Mohanta KN, Mohanty SN, Jena JK, Sahu NP (2008) Optimal dietary lipid leve of silver barb, Puntius gonionotus, fingerlings in relation to growth, nutrient retention and digestibility, muscle nucleic acid content and digestive enzyme activity. Aquaculture Nutrition 14: 350-359.

32. Munilla-Morán R, Saborido-Rey F (1996) Digestive enzymes in marine species. I. Proteinase activities in gut from redfish (Sebastes mentella) seabream (Sparus aurata) and turbot (Scophthalmus maximus). Comparative Biochemistry and Physiology B 113: 395-402

33. Chong ASC, Hashim R, Chow-Yang L, Ahyaudin BA (2002) Partia characterization and activities of proteases from the digestive tract of discus fish (Symphysodon aequifasciata). Aquaculture 203: 321-333. 